\title{
Delayed Manifestation of Sacral Clear Cell Meningioma Distent Metastasis or Multifocal Disease?
}

\author{
Habib Nouri ${ }^{1}$, Leila Abid ${ }^{2}$, Moez Ouertatani ${ }^{1}$, Dalenda Hentati ${ }^{3}$, Mondher Mestiri ${ }^{2}$, Habib Jaafoura ${ }^{2}$ \\ ${ }^{1}$ Department of "Adult" Surgery, Kassab's Institute, Tunisia \\ ${ }^{2}$ Department of "Pathology", Kassab's Institute, Tunisia \\ ${ }^{3}$ Department of Radiation Therapy, National Institute of Oncology, Tunisia \\ E-mail: nourihabib@yahoo.fr \\ Received December 6, 2010; revised December 26, 2010; accepted January 13, 2011
}

\begin{abstract}
Study Design: the authors report on a clear cell meningioma (CCM) of the sacrum revealed 17 years after a removal of a spinal lesion. A review of 29 spinal CCM previously reported was done. Objective: To focus on clinical and biological behaviour of CCM. Summary of Background Data: CCM is a rare subtype characterrized by its inordinately aggressive clinical course despite its benign appearance. The tumour shows proclivity for the cerebellopontine angle and cauda equine region. Recurrence and metastasis have been commonly reported. Method: a 26 year-old man presented with low back pain related to a lytic lesion of the sacrum. He had a history of an intradural extramedullary meningioma of the cervical spine removed when he was 9 year-old. CT scan revealed a sacral osteolytic lesion with anterior and lateral extension. Open biopsy revealed a clear cell meningioma. That was the same pattern of the tumour removed 17 years before. Results: Our patient was managed conservatively by palliative radiation therapy. At 2 years follow-up, he experienced improvement of pain and walking. Conclusion: CCM is an aggressive tumour with a high risk of metastases through cerebrospinal fluid. A follow up with spinal MRI should be performed.
\end{abstract}

Keywords: Clear Cell Meningioma, Spine, Cerebrospinal Fluid, Metastasis, Local Recurrence, Radiation Therapy, Pathology

\section{Introduction}

Meningiomas are the most common primary tumours of the central nervous system. Approximately $90 \%$ to $95 \%$ of them are classified as grade I according to the World Health Organization (WHO) 2007 criteria [1], whereas 5 to $7 \%$ are graded II and 1 to $2.8 \%$ are graded III. Clear cell meningiomas (CCM) are rare and have been reported in only $0.2 \%$ of cases [2]. They are graded II or aggressive. The tumour shows proclivity for the cerebellopontine angle and cauda equine region. Despite its benign appearance, CCM has an aggressive behaviour and recurrence and metastasis has been commonly reported.

Here we report an unusual case of a metastatic clear cell meningioma to the sacrum, discovered 17 years after total resection of the primary cervical lesion. The clinical and pathological features are discussed.

\section{Case Report}

A 26 year-old male was referred to our department in 2007 for a tumour of the sacrum. He underwent in 1990 when he was 9 year-old a resection of an intraspinal tumour. Cervical CT scan had revealed an intraduralextramedullary tumor measuring $2 \mathrm{~cm}$ at the level of C4-C5. The tumor was well-circumscribed, homogeneous, located posteriorly, and compressing the spinal cord. The tumor was excised totally. Pathological examination had revealed a particular meningioma characterized by the presence of mycrocystic cells and prominent interstitial collagen which separate or enclose the cellular aggregates. A Masson's trichrome stain highlighted the abundant collagen component. The neoplastic cells were arranged in sheets and forming a rare whorls. The stromal blood vessels have a thick hyalinized wall. The patient got no further therapy and follow-up was uneventful for 


\section{7 years.}

His complaints were progressive sacral pain and constipation. There was neither mass nor neurological deficit in clinical findings.

Plain radiographs showed a radiolucent expansion of the sacrum (Figure 1). Pelvic CT scan revealed a huge mass involving the entire sacrum, expanding anteriorly and invading the ilio-sacral joints (Figures 2(a) and (b)). Cervical spinal CT scan didn't show any local recurrence of the primary lesion.

An open biopsy in the sacrum was performed. Histologically, the tumour was composed of sheets of polygonal cells with clear cytoplasm and prominent interstitial collagen (Figure 3(a)). Neoplastic cells had vesicular, round to oval nuclei and small nucleoli. There was no significant cytological atypia or pleomorphism. No mitotic figures were identified (Figure 3(b)). The cells have an abundant clear cytoplasm PAS-positive due to glycogen accumulation. In particular, there were numerous concentrically laminated eosinophilic, collagenous structures intersecting throughout the lesion. However, typical psammoma bodies were not seen. Only, a few vague whorls were seen. Extensive immunohistochemistry has been performed. The neoplastic cells stained strongly diffuse positivity for vimentin. The tumor cells were also positive for EMA and S100. Moderate positivity was demonstrated with progesterone receptor (Figure 3(c)). The cells showed negative staining with cytokeratin, chromogranine and glial fibrillary protein. The reactivity of the tumor cells with the antibody MIB-1 showed a very low labelling index and the percentage of cells that expressed MIB-1 was about $1 \%$.

On the basis of these histological findings, the diagnosis was that of clear cell meningioma. Primary histological specimens taken at the age of 9 years were available for study and showed the same features of the sacral tu-

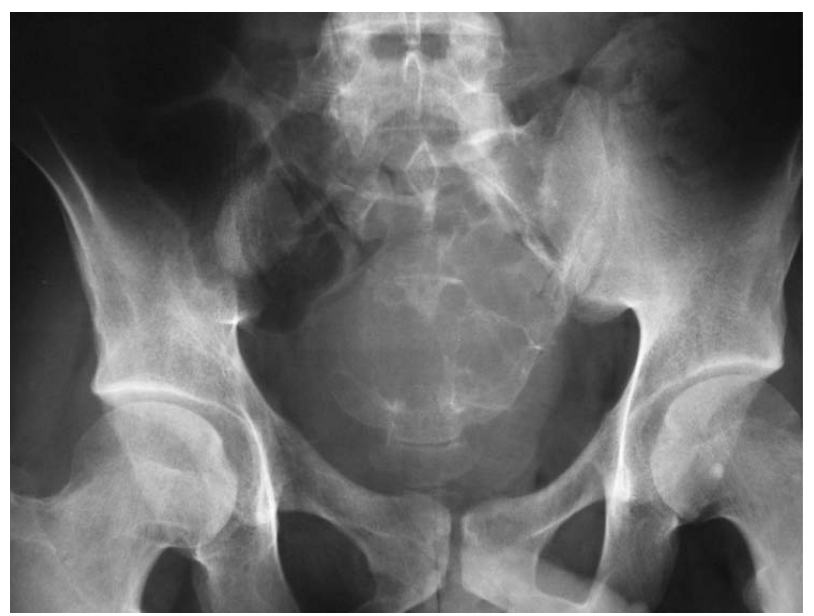

Figure 1. Plain radiographe AP view showing a radiolucent expension of the sacrum.

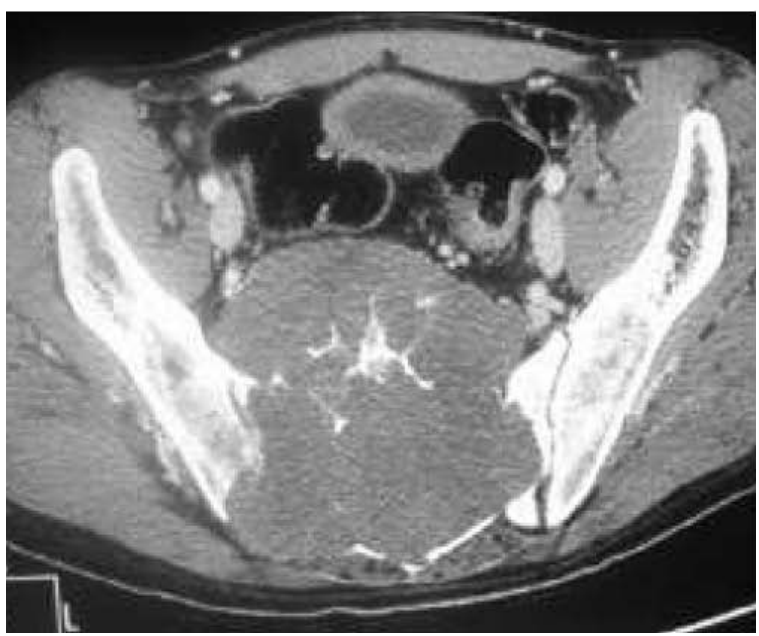

(a)

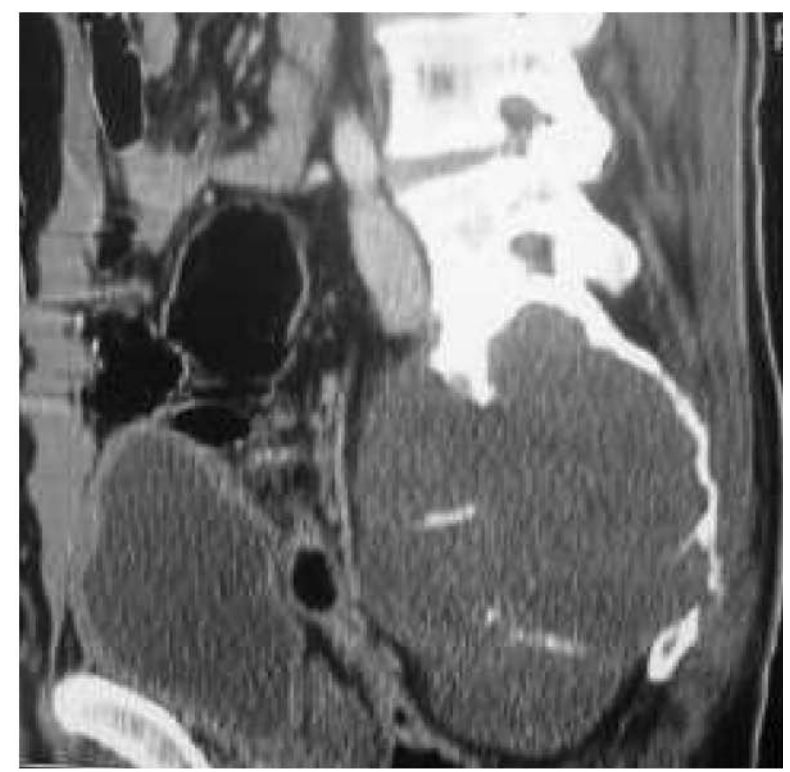

(b)

Figure 2. CT scan of the pelvis. (a) axial view showing an osteolytic lesion of the sacrum invading the intrapelvic organs anteriorly and the ilio-sacral joints laterally; (b) sagittal reconstruction. The tumor mass invaded the spinal canal and the presacral space. Note that posterior extension is limited.

mour. Therefore we concluded to an osseous metastatic clear cell meningioama. Chest CT scan was negative. The patient received palliative radiation therapy consisting of 6000 cGy delivered in 30 fractions. Four years later, he was still alive, he experienced improvement of pain. The mass was stable on control CT scan (Figure 4).

\section{Discussion}

Our case with primary extracranial CCM and the so far metastasis to the sacrum is unique. It presented mainly 2 


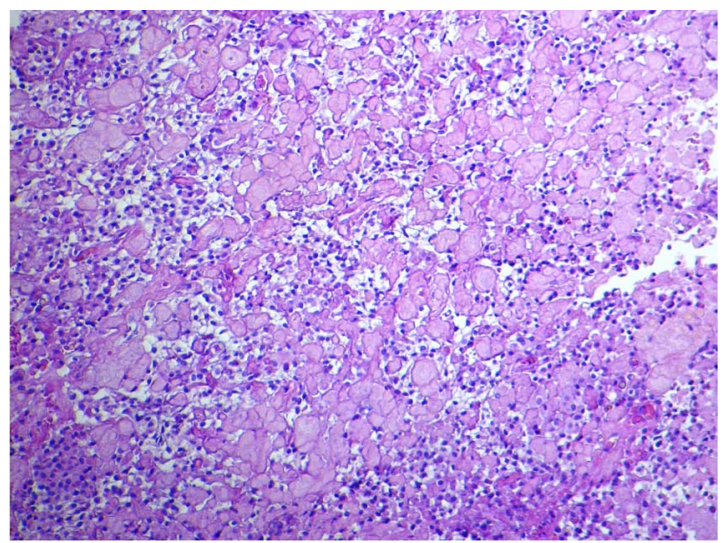

(a)

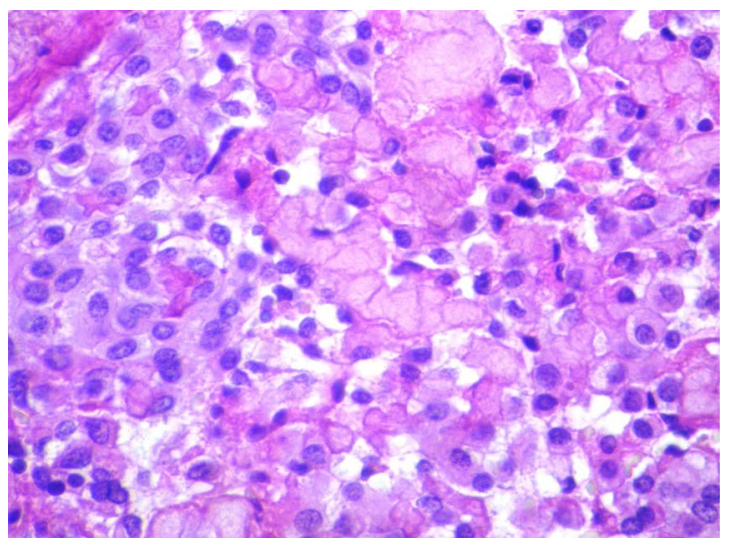

(b)

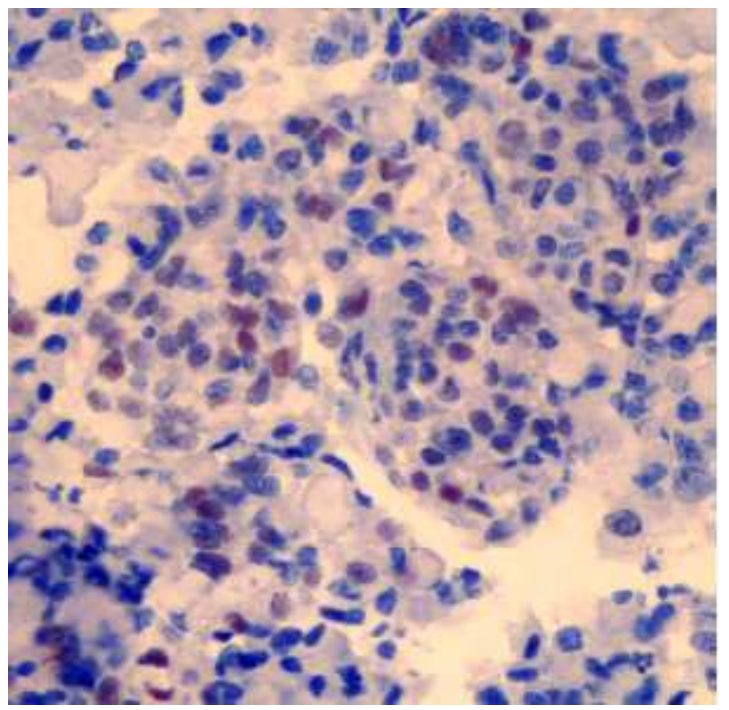

(c)

Figure 3. (a) Microscopically, the tumour is composed of patternless sheets of clear-cells in a collagen background (Hematoxylin and eosin, original magnification $\times 200$ ); (b) neoplastic cells had vesicular, round to oval nuclei and small nucleoli. The cells have an abundant clear cytoplasm PAS-positive; (c) tumour cells show a moderate immunoreactivity for progesterone receptor.

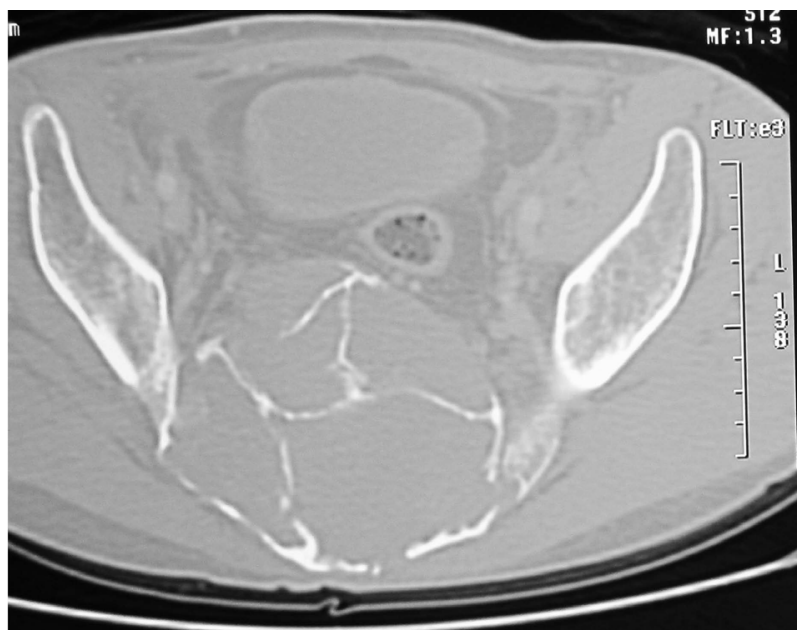

Figure 4. CT scan 4 years later. The mass is stable.

problems, a therapeutic one characterised by the absence of a consensus in literature. Secondly, the relationship between the present tumor and the primary cervical lesion remains unclear.

Clear cell meningioma is perhaps the rarest of the tumors of meningothelial origin. Among 485 cases, K-W ko et al. [3] found 3 CCMs $(0.6 \%)$. Zorludemir et al. [2] reported the largest series of 13 cases of CCM. The most frequent site of involvement was the spinal intradural region $(56 \%)$. Twenty nine documented cases of spinal $\mathrm{CCMs}$ reported previously were found from literature [2,4-24]. Clinical data and outcome are summarised in the Table 1. CCM seems to affect young patient with a mean age of 22.4 years +/-18.2 (median: 19 years), although both paediatric and elderly patients are involved (1.2 - 72 years). It appears to be a female predominance (F/M: 1.72). The most frequent location observed was the cauda equine. Cervical spine was involved in 5 cases only $(16.7 \%)$.

The importance of recognising this particular variant of meningioma relates specifically to its inordinately aggressive clinical course despite its benign appearance. Unlike the more typical meningioma, CCM's propensity for local recurrence has been well-established in the literature. The rate of recurrence found in this study was $40 \%$ (vs $4.8 \%$ for non CCMs) [25,26]. Although rare event $(7 \%)$, spinal metastasis in meningiomas is well established [25,27-33]. It occurs either through haematogenous route or cerebro-spinal fluid. Metastases occur in aproximately $0.2 \%$ of intracranial tumours [33]. Only $7 \%$ of them occur in vertebrae $[33,34]$ and not all meningiomas that metastasize are malignant. More than $60 \%$ of them originated from grade I meningiomas $[26,29]$. Nevertheless, distant metastases are known to be relatively more frequent arising from grade II or III subtypes $[35,36]$. Malignant meningiomas seem to spread 
through CSF more frequently [29,37-39]. However the risk of CSF dissemination is not clear from literature. It remains controversial whether surgical procedures may play a role in the spread of the tumour via CSF $[37,38]$. Most of patients were operated on several times before a metastasis occurred. Although, some cases seem to occur in non-operated patients $[26,40]$. The lumbo-sacral region was a common site for spinal metastases [27]. The first case of a metastatic meningioma to the sacrum was reported by Lee [29] in 2002. However, whether distant recurrences represent the capacity of CCM to metastasize or a multifocal characteristic remains uncertain. Multifocal manifestation of CCM is well-described and the distant recurrences may represent this [41]. To our know- ledge, only one documented case of synchronous multicentric CCM was reported [9]. Our case seems to be more likely a distant recurrence because of a drop metastasis rather than a multifocal presentation but we couldn't conclude since the entire neuraxis was not imaged initially. This emphasizes the necessity to explore the entire spine by MRI in cases of spinal meningioma.

The latency period between the diagnosis of primary tumour and the appearance of metastasis reported in literature is variable, ranging from few months to more tan 20 years [41]. In our case, the latency of 17 years can be explained by two facts: firstly, the very low mitotic activity attests that it's a slow growing lesion. Secondly, the location to the sacrum and the anterior extension of

Table 1. Summary of intraspinal CCMs observed in present and previous reports. GTR: gross total resection; STR: subtotal resection; $\mathrm{RT}$ : radiation therapy.

\begin{tabular}{|c|c|c|c|c|}
\hline Author/year & Age/sex & Tumor location & Treatment & Outcome (recurrence metastasis) \\
\hline Zorludemir (2) 1995 & $\begin{array}{c}9 / \mathrm{F} 17 / \mathrm{F} \\
23 / \mathrm{F} 34 / \mathrm{M} \\
36 / \mathrm{F} 47 / \mathrm{M}\end{array}$ & $\begin{array}{l}\text { L3-L5 L4-L5 } \\
\text { L5 L4-S1 } \\
\text { L2-L5 L3-L4 }\end{array}$ & $\begin{array}{c}\text { GTR GTR } \\
\text { GTR GTR } \\
\text { GTR GTR + RT }\end{array}$ & $\begin{array}{l}\text { Recurrence at } 6 \text { months No No } \\
\text { Recurrence at } 2 \text { months No } \\
\text { Recurrence at } 36 \text { months, and brain metastasis }\end{array}$ \\
\hline Prinz (4) 1996 & $38 / \mathrm{M}$ & Sacrococcygeal & GTR & Multiple recurrences \\
\hline Holtzman (5) 1996 & $32 / \mathrm{M}$ & L3-L4 & GTR & No \\
\hline Pimentel (6) 1998 & $55 / \mathrm{M} 21 / \mathrm{F}$ & Cervical Lumbar & GTR GTR & No No \\
\hline Cances (7) 1998 & $9 / \mathrm{F}$ & L1-L4 & $\mathrm{GTR}+\mathrm{RT}$ & Recurrence at 5 months \\
\hline Dubois (8) 1998 & $10 / \mathrm{F}$ & Cauda equine & $\mathrm{GRT}+\mathrm{RT}$ & Recurrence at 6 months \\
\hline Matsui (9)1998 & $9 / \mathrm{F}$ & Multifocal T12, L2, L5 & GTR & No \\
\hline Yu (11) 2002 & $1.2 / \mathrm{F}$ & T12-L1 & GTR & Recurrence at 4 months \\
\hline Boet (12) 2004 & $34 / \mathrm{M}$ & Lumbosacral & $\mathrm{STR}+\mathrm{RT}$ & No \\
\hline Liu (13) 2005 & $2.2 / \mathrm{F}$ & T10-L1 & GTR & Recurrence at 60 months \\
\hline Dhall (14) 2005 & $32 / \mathrm{F}$ & Thoraco lumbar & STR & Recurrence \\
\hline Jain (15) 2007 & $26 / \mathrm{F}$ & Cauda equine & GTR & No \\
\hline Colen (16) 2009 & $13 / \mathrm{F}$ & L4-L5 & $\mathrm{GTR}+\mathrm{RT}$ & No \\
\hline Tong-tong (17) 2010 & $35 / \mathrm{F}$ & $\mathrm{C} 7$ & GTR & No \\
\hline Inoue (18) 2004 & $72 / \mathrm{M}$ & C5-C6 & GTR & No \\
\hline Epstein (21) 2005 & $41 / \mathrm{F}$ & L3-L4 & GTR & No \\
\hline Park (22) 2000 & $1.2 / \mathrm{F}$ & Cauda equine & GTR & Recurrence at 18 months \\
\hline Carra (23) 2001 & $1.9 / \mathrm{M}$ & T11-L4 & GTR & No \\
\hline Chen (24) 2004 & $41 / \mathrm{F}$ & L4-L5 & GTR & No \\
\hline Present report & 9/M & $\mathrm{C} 4$ & GTR & Sacral metastasis at 17 years \\
\hline
\end{tabular}


the tumour explain how such a huge mass could remain asymptomatic for a long period.

Prognosis of spinal metastases is related to their clinical progression. When it was rapid, death usually occurred soon after the time of initial diagnosis. The prognosis is especially bad in patients with neurologic deficit.

Treatment of spine metastatic meningiomas is palliative. Patients that had undergone surgical debulking $[27,28,31,35,36,42]$ showed no neurological improvement. Palliative radiation therapy is the preferred modality of treatment. Although, irradiation has shown some symptomatic relief, the paucity of cases doesn't allow clear conclusions concerning its real effect on survival rate. Lee et al [38] used steroid for their 3 patients combined to irradiation and reported some symptomatic improvement. Adjunction of steroid seems to be interesting since neoplastic cells demonstrate positivity for progesterone receptors.

\section{Conclusions}

Clear cell meningioma constitutes a rare subset of malignant meningiomas. It has an aggressive clinical course despite its histological appearance. A close follow-up would be required due to the high risk of recurrence and metastases. The early detection and irradiation of metastatic lesions can improve their prognosis.

\section{References}

[1] D. Louis, Ohgaki, H. Wiestler, et al., "WHO Classification-Tumours of the Nervous System," 4th Edition, International Agency for Research on Cancer, Lyon, 2007, pp. 164-172.

[2] S. Zorludemir, B. W. Scheithauer, T. Hirose, et al., "Cler Cell Meningioma: A Clinicopathologic Study of a Potentially Aggressive Variant of Meningioma," The American Journal of Surgical Pathology, Vol. 19, No. 5, 1995, pp. 493-505. doi:10.1097/00000478-199505000-00001

[3] K. W. Ko, D. H. Nam, D. S. Kong, et al., "Relationship between Malignant Subtypes of Meningioma and Clinical Outcome," Journal of Clinical Neuroscience, Vol. 14, No. 8, 2007, pp. 747-753. doi:10.1016/j.jocn.2006.05.005

[4] M. Prinz, S. Patt, T. Mitrovics, et al., "Clear Cell Meningioma: Report of a Spinal Case," General \& Diagnostic Pathology, Vol. 141, No. 3-4, 1996, pp. 261-267.

[5] R. N. N. Holtzman and S. C. Jorkman, "Nondural-Based Lumbar Clear Cell Meningioma," Journal of Neurosurgery, Vol. 84, No. 2, 1996, pp. 264-266. doi:10.3171/jns.1996.84.2.0264

[6] J. Pimental, A. Fernandes, A. E. Pinto, et al., "Clear Cell Meningioma Variant and Clinical Aggressiveness," Clinical Neuropathology, Vol. 17, No. 3, 1998, pp. 141-146.

[7] C. Cances, Y. Chaix, C. Karsenty, et al., "Clear Cell Meningioma: Recurrent Intraspinal Tumor in a Child," Ar- chives de Pédiatrie, Vol. 5, No. 7, 1998, pp. 758-762. doi:10.1016/S0929-693X(98)80062-6

[8] A. Dubois, A. Sevely, S. Boetto, et al., "Clear Cell Meningioma of the Cauda Equine," Neuroradiology, Vol. 40, No. 11, 1998, pp. 743-747. doi:10.1007/s002340050676

[9] H. Matsui, M. Kanamori, Y. Abe, et al., "Multifocal Clear Cell Meningioma in the Spine: A Case Report," Neurosurgical Review, Vol. 21, No. 2-3, 1998, pp. 171-173. doi:10.1007/BF02389326

[10] G. I. Jallo, K. F. Kothbauer, V. M. Silvera, et al., "Intraspinal Clear Cell Meningioma: Diagnosis and Management: Report of Two Cases," Neurosurgery; Vol. 48, No. 1, 2001, pp. 218-222.

[11] K. B. Yu, M. K. Lim, H. J. Kim, et al., "Clear Cell Meningioma: CT and MR Imaging Findings in Two Cases Involving the Spinal Canal and Cerebellopontine Angle," Korean Journal of Radiology, Vol. 3, No. 2, 2002, pp. 125-129. doi:10.3348/kjr.2002.3.2.125

[12] R. Boet, H. K. Ng, S. Kumta, et al., "Lumbosacral Clear-Cell Meningioma Treated with Subtotal Resection and Radiotherapy," Journal of Clinical Neuroscience, Vol. 11, No. 4, 2004, pp. 432-436. doi:10.1016/j.jocn.2003.10.014

[13] P. I. Liu, G. C. Liu, K. B. Tsai, et al., "Intraspinal Clear Cell Meningioma: Case Report and Review of Literature," Surgical Neurology, Vol. 63, No. 3, 2005, pp. 285-289. doi:10.1016/j.surneu.2004.03.013

[14] S. S. Dhall, L. M. Tumialan, D. J. Brat, et al., "Spinal Intradural Clear Cell Meningioma Following Resection of a Suprasellar Clear Cell Meningioma. Case Report and Recommendations for Management," Journal of Neurosurgery, Vol. 103, No. 3, 2005, pp. 559-563. doi:10.3171/jns.2005.103.3.0559

[15] D. Jain, M. C. Sharma, C. Sarkar, et al., "Clear Cell Meningioma, an Uncommon Variant of Meningioma: A Clinicopathologic Study of Nine Cases," Journal of Neuro-Oncology, Vol. 81, No. 3, 2007, pp. 315-321. doi:10.1007/s11060-006-9237-7

[16] C. B. Colen, M, Rayes, J. McClendon Jr., et al., "Pediatric Spinal Clear Cell Meningioma. Case Report," Journal of Neurosurgery Pediatrics, Vol. 3, No. 1, 2009, pp. 57-60.

[17] T.-T. Wu, L.-J. Bian, Z. Li, Y. Li, B.-N. Luo and Q. Huang, "Clear Cell Meningioma with Anaplastic Features: Case Report and Review of Literature," Pathology-Research and Practice, Vol. 206, No. 5, 2010, pp. 349-354. doi:10.1016/j.prp.2009.06.015

[18] T. Inoue, K. Miyamoto, H. Kodama, et al., "Cervical Clear Cell Meningioma Mimicking a Vertebral Metastasis," Journal of Clinical Neuroscience, Vol. 12, No. 6, 2005, pp. 685-687. doi:10.1016/j.jocn.2004.08.019

[19] J. A. Heth, P. Kirby, A. H. Menezes, et al., "Intraspinal Familial Clear Cell Meningioma in a Mother and Child," Journal of Neurosurgery, Vol. 93, No. 2, 2000, pp. 317-321.

[20] A. Oviedo, D. Pang, J. Zovikian, et al., "Clear Cell Meningioma: Case Report and Review of the Literature," Pe- 
diatric and Developmental Pathology, Vol. 8, No. 3, 2005, pp. 386-390. doi:10.1007/s10024-005-0119-3

[21] N. Epstein, S. Drexler and J. Shneider, "Clear cell Meningioma of the Cauda Equine in an Adult. Case Report and Literature Review," Journal of Spinal Disorders \& Techniques, Vol. 18, No. 6, 2005, pp. 539-543. doi:10.1097/01.bsd.0000173314.98401.b5

[22] H. C. Park, M. J. Sohn, E. Y. Kim, et al., "Spinal Clear Cell Meningiomas Presented with Progressive Parapresis in Infancy," Child's Nervous System, Vol. 16, No. 9, 2000, pp. 607-610. doi:10.1007/PL00007302

[23] S. Carra, P. Drigo, M. Gadriman, et al., "Clear Cell Meningioma in a 22 Months-Old Male; a Case Report and Literature Review," Pediatric Neurosurgery, Vol. 34, No. 5, 2001, pp. 264-267.

[24] M. H. Chen, S. J. Chen, S. M. Lin, et al., "A Lumbar Cleare Cell Meningioma with Foraminal Extension in a Renal Transplant Recipient," Journal of Clinical Neuroscience, Vol. 11, No. 6, 2004, pp. 665-667. doi:10.1016/j.jocn.2003.10.024

[25] S. K. Ludwin and F. K. Conley, "Malignant Meningioma Metastatizing through the Cerebrospinal Pathways," Journal of Neurology, Neurosurgery \& Psychiatry, Vol. 38, No. 2, 1975, pp. 136-142. doi:10.1136/jnnp.38.2.136

[26] P. M. Son, M. Sacher, S. W. Strenger, et al., "Benign Metastasizing Meningiomas," American Journal of Neuroradiology, Vol. 8, No. 1, 1987, pp. 127-130.

[27] A. T. kimura, T. Orita, O. Hayashida, et al., "Malignant Meningiomas Metastatizing through the Cerebrospinal Pathway," Acta Neurologica Scandinavica, Vol. 85, No. 5, 1992, pp. 368-371. doi:10.1111/j.1600-0404.1992.tb04063.x

[28] K. Kamiya, T. Inagawa and R. Nagasako, "Malignant Intraventricular Meningioma with Spinal Metastasis through the Cerebrospinal Fluid," Surgical Neurology, Vol. 32, No. 3, 1989, pp. 213-218. doi:10.1016/0090-3019(89)90181-X

[29] Y. Y. Lee, W. W. Hsu, T. J. Huang, et al., "Metastatic Meningioma in the Sacrum: A Case Report," Spine, Vol. 27, No. 4, 2002, pp. E100-E103. doi:10.1097/00007632-200202150-00022

[30] W. C. Peh and Y. W. Fan, "Case Report: Intraventricular Meningioma with Cerebelopontine Angle and Drop Metastases," The British Journal of Radiology, Vol. 68, No. 808, 1995, pp. 428-430. doi:10.1259/0007-1285-68-808-428

[31] C. G. Riley, "Metastatizing Meningeal Tumour Case Report," The New Zealand Medical Journal, Vol. 73,
1974, pp. 210-214.

[32] F. J. Wippold II, J. G. Smimoitopoulos and T. K. Pilgram, "Lesions of the Cauda Equine: A Clinical Pathology Review from the Armed Forces Institute of Pathology," Clinical Neurology and Neurosurgery, Vol. 9, No. 4, 1997, pp. 229-234. doi:10.1016/S0303-8467(97)00095-4

[33] J. L Karasik and S. Mullens, "A Survey of Metastatic Meningiomas," Journal of Neurosurgery, Vol. 40, No. 2, 1974, pp. 206-212. doi:10.3171/jns. 1974.40.2.0206

[34] R. Wasserkurg, E. Peyser and C. Lichtig, "Extracranial Bone Metastases from Intracranial Meningiomas," Surgical Neurology, Vol. 12, No. 6, 1979, pp. 480-484.

[35] M. D. Conrad, C. Schonauer, I. Pelissou-Guyotat, et al., "Recurrent Lumbosacral Metastases from Intracranial Meningioma. Report of a Case and Review of the Literature," Acta Neurochirurgica, Vol. 143, No. 9, 2001, pp. 935-937. doi:10.1007/s007010170024

[36] S. A. Enam, S. Abdulrauf, B. Mehta, et al., "Metastasis in Meningioma," Acta Neurochirurgica, Vol. 138, No. 10, 1996, pp. 1172-1178. doi:10.1007/BF01809747

[37] M. C. Chamberlain and M. J. Glantz, "Cerebrospinal FluidDessiminated Meningioma," Cancer, Vol. 103, No. 7, 2005, pp. 1427-1430. doi:10.1002/cncr.20926

[38] T. T. Lee and H. J. Landy, "Spinal Metastases of Malignant Intracranial Meningioma," Surgical Neurology, Vol. 50, No. 5, 1998, pp. 437-441. doi:10.1016/S0090-3019(97)00348-0

[39] P. D. Delgado-Lopez, V. Martin-Velasco, J. M. CastillaDiez, et al., "Metastatic Meningioma to the Eleventh Dorsal Vertebal Body: Total En Bloc Spondylectomy. Case Report and Review of the Literature," Neur- ocirurgia, Vol. 17, No. 3, 2006, pp. 240-249.

[40] S. W. Strenger, Y. P. Huang and V. P. Sachdez, "Malignant Meningioma within the Third Ventricle: A Case Report," Neurosurgery, Vol. 20, No. 3, 1978, pp. 465-468. doi:10.1227/00006123-198703000-00019

[41] W. Lee, K. H. Chang, G. Choe, et al., "MR Imaging Features of Clear Cell Meningioma with Diffuse Lep- tomeningeal Seeding," American Journal of Neuroradiology, Vol. 21, No. 1, 2000, pp. 130-132.

[42] S. Fuentes, P. Metellus, C. Bouvier, et al., "Metastatic Meningioma to the First Thoracic Vertebral Body. A Case Report and Review of the Literature," Neurochirurgie, Vol. 48, No. 1, 2002, pp. 53-56. 